\title{
Relationship of First-Year University Grades of Non-High School Graduates with the Tests of General Educational Development
}

\author{
J. DOUGLAS AYERS
}

\begin{abstract}
The Tests of General Educational Development (GED) are used extensively in the United States and in all provinces and territories in Canada except Quebec, Ontario, and Alberta for high school equivalency certification. The five tests, which include English, Social Studies, Natural Sciences, Literature, and Mathematics, measure reading comprehension and general knowledge in the subjects rather than specific content of secondary school courses. Nevertheless, they tend to be good predictors of success in colleges and universities. Where these institutions do not have an open admission policy, it is recommended that they determine relative cut-off points for admission to programs. Results of this study indicate that where such cut-off points have been established, they may be at an unnecessarily high level; also, that an open admission policy, especially if supported by remedial English and study skills courses, may be advisable.
\end{abstract}

\section{RÉSUMÉ}

Les tests du Développement Général Educatif (DGE) sont utilisés de manière extensive aux Etats-Unis et dans toutes les provinces et territoires du Canada, excepté au Québec, en Ontario, et en Alberta, pour la certification d'équivalence en école secondaire. Les 5 tests, qui comprennent de l'anglais, des études sociales, des sciences naturelles, de la littérature et des mathématiques, évaluent une compréhension à la lecture et une culture générale dans les matières plutôt que le contenu spécifique aux cours d'école secondaire. Néanmoins, ils ont tendance a bien prédire l'éventuel succès dans les collèges et les universités. Là où ces institutions ne stipulent pas d'admission ouverte, il est recommandé qu'elles déterminent un numerus clausus relatif pour les admissions aux programmes. Les résultats de cette enquête montrent que là ou de tels numerus clausus ont été institués, 
76 J. Douglas Ayers

il se peut qu'ils le soient à un niveau inutilement élevé; de même, qu'une politique d'admission ouverte, spécialement si elle est appuyée par de l'anglais de rattrapage et une étude de cours d'aptitudes, peut être conseillée.

The Tests of General Educational Development (GED) provide the non-high school graduate with the opportunity to obtain a high school equivalency certificate which has generally been accepted as the equivalent of a regular high school diploma by civil service commissions, business organizations, and institutions of higher learning in the United States. In Canada the GED has been gaining similar recognition in all provinces and territories except Quebec, Ontario and Alberta.

The GED battery consists of five tests in the areas of English, Social Studies, Natural Sciences, Literature, and Mathematics. The tests are not oriented toward the typical content of courses offered in secondary schools, rather they emphasize reading comprehension, intellectual ability and general knowledge. Three of the tests involve interpretation of reading material in the social studies, natural sciences, and literature. Test 1 emphasizes mechanics of expression, and to a lesser extent, effectiveness of expression in English; while Test 5, entitled "General Mathematical Ability" includes basic mathematics with very little high school algebra, geometry, or trigonometry. In practice, a number of institutions preparing students for the GED require a reading comprehension score of Grade 9 to Grade 9.5 on published standardized tests to screen those who will be unsuccessful on the GED. In many ways, therefore, it would be appropriate to think of these tests as measures of general ability and reading comprehension, rather than high school "equivalency" examinations. They should, however, still be good predictors of success in institutions of higher learning.

Considering the wisespread use of the GED, it is surprising to find very few studies that evaluated the test's validity for admission of non-high school graduates to institutions of higher education. Only two, Beusse (1972) and Sharon (1972), were found to be published in the period since 1971 , and that by Beusse was concerned primarily with variables that predicted success in completion of the GED with the armed services.

Sharon (1972) critized previous studies but did not cite any specifically, on the basis that they were conducted within single institutions, thus making it difficult to generalize because of the diverse populations, admission standards, and grading practices. His study was conducted in 12 junior colleges and 28 four-year institutions. The correlations, based generally on two-year GPA's adjusted for different grading standards, were significant but small, especially for the four-year institutions. For the two-year institutions, the correlations ranged from .33 to .51 , and for the four-year institutions from .25 to .34 . Sharon hypothesized that the higher correlations for the two-year colleges indicated that the GED provides a better measure of abilities necessary for success in initial college courses than for higher level courses. However, dropout and restriction of grade ranges for higher level courses are probably more valid explanations for the lower correlations. Another problem with grouping institutions as Sharon has done, is generally to reduce the predictive validity because of the pooling. Many individual institutions would have higher correlations than those reported by him for either the two-year or four-year institutions. Sharon also 
found that the correlations for a selected sample when grouped by age, under and over thirty, were somewhat higher ranging from .35 to .52 . Correlations with attrition, however, were no higher than .20 .

While Sharon's study showed that age and type of college affect the predictive validity of the tests, such information is not useful in determining cut-off points on the GED for entry to individual institutions. Moreover, it does not provide information that would be useful in establishing policy with regard to the use of the GED for entrance to institutions of higher education. This is because the predictive efficiency of any selection device is not simply a function of the size of the correlation between the selection instrument such as the GED test and the criterion such as course grades. Predictive efficiency is determined by both the "selection ratio", that is the standard established for entry to a program and the "success ratio", the level established for satisfactory/unsatisfactory performance. It is essential, therefore to study distributions on both the predictor and criterion variables (Mehrens and Lehmann, 1978).

Ideally, of course, each institution should establish its own cut-off points based on at least one study with open admission. This was the thrust of the study reported here with its primary aim to determine the effectiveness of the GED battery as an instrument to select non-high school graduates for a university program operating in two federal prisons in Canada. Specifically the study was to determine:

1. the extent of common variance in the GED tests and the first-year university courses,

2. variation in early drop-out rates according to language of earlier schooling,

3. effectiveness of GED average scores for the selection of students for the university program at the federal prisons,

4. relationships between grades on first-year subjects and each of the five GED tests, and average score, especially with respect to a fail criterion.

Additionally, it was intended to study the stability of pass-fail results over the fouryear period 1974-1977. Indirectly, it was hoped to determine if there was any validity in the University of Victoria requiring a cutoff point of 58.5 on the average standard score for mature students on campus.

The program originated as an experiment in April ' 72 but has continued as a regular program since September ' 72 , offering first and second year courses primarily in the humanities and social sciences, with first-year English and history courses being compulsory. By 1976, third and fourth year courses were offered, which provided an opportunity for prison students to obtain general degrees with specialization in four areas: English, History, Psychology, and Sociology.

Since the program started, students have been admitted under the "mature" category, but from August ' 73 when the program became the earliest user of the GED in British Columbia, all students have been required to take the GED except those with Grade 12 or university transfer credit. An average standard score of 45 has been required for entry except for students for whom English is a second language. Program students are thus relatively unselected compared with on-campus, making it easier to determine the effect of different cutoff points on success and failure. A preliminary study conducted a few years ago, but based on a limited number of cases, suggested the cutoff point should be 
Table 1

VARIMAX FACTOR ANALYSIS OF GED TESTS AND FIRST YEAR COURSES

\begin{tabular}{llcc} 
& \multicolumn{3}{c}{ F A C T O R S } \\
\cline { 2 - 4 } Variable & G E D & Academic & Composition \\
\cline { 2 - 4 } Test 1 - English Expression & $0.795^{\star}$ & 0.024 & 0.130 \\
Test 2 - Social Studies & $0.741^{\star}$ & 0.041 & $0.468^{\star}$ \\
Test 3 - Natural Sciences & $0.824^{\star}$ & 0.118 & 0.142 \\
Test 4 - Literary Materials & $0.898^{\star}$ & 0.225 & 0.081 \\
Test 5 - Mathematical & $0.718^{\star}$ & 0.341 & -0.137 \\
Test 6 - Total GED & $0.966^{\star}$ & 0.177 & 0.163 \\
Eng. 111-115 & 0.087 & 0.121 & $0.882^{\star}$ \\
Eng. 121-122 & 0.049 & $0.843^{\star}$ & 0.032 \\
Hist. 230-240-242 & 0.214 & $0.503^{\star}$ & 0.286 \\
Psych. 100 & 0.261 & $0.484^{\star}$ & $0.529^{\star}$ \\
Soci. 100 & 0.158 & $0.711^{\star}$ & 0.107 \\
Other & 0.082 & $0.511^{\star}$ & $0.496^{\star}$ \\
\hline & 4.270 & 2.195 & 1.706 \\
\hline Percent of Common Variance & 52.260 & 26.861 & 20.878 \\
Percent of Total Variance & 35.582 & 18.289 & 14.215 \\
\hline * - Loadings that define the factor. & & \\
\hline
\end{tabular}

in the range of 52 to 55 , which is considerably lower than that used on campus. Because of the small numbers entering the program each term, it was decided to base this study on data collected over a four-year period. It was also hoped that such a study might reveal trends in standards and/or procedures.

\section{Method}

For each student that entered the program after January 1, 1974, data were collected on time of drop-out, language of earlier schooling, and grades obtained on all first-year courses, as well as GED results. The data were then subjected to various analyses, related to the four specific purposes outlined above. The analyses included a factor analysis with varimax rotation for the GED tests and first-year courses; the rate of early drop out by language of schooling, the distributions of students showing the number who completed three months or more by GED average score and year of entry; and distributions of grades for each subject by each GED test and average standard score.

\section{Results and Discussion}

The factor analysis reported in Table 1 shows three main factors labelled GED, Academic, and Composition. The three factors accounted for 70 per cent of the total variance with the GED being the primary factor with slightly over 50 per cent of the common variance. This is not surprising in view of the homogeneity of the materials in the GED tests discussed earlier. Weightings above .40 that define the factor are indicated by an asterisk. 
The only variables in the GED factor are the GED tests themselves. All of the courses, except English Composition, are weighted in the Academic factor, while the Composition factor is represented mainly with English Composition but has minor contributions from GED Social Studies, Psychology, and other subjects.

Early drop-out was determined by studying time of drop-out in the English composition course which is required of everyone in the first term. Only 21 per cent of those with earlier schooling in English dropped out early, whereas for those with French or native backgrounds, the rate was 40 per cent; while for those from other countries, the early drop-out rate was 67 per cent.

The data presented in Table 2 shows the distribution of students who completed three months or more of the program by standard scores on the various GED tests and by year of entry. Whether one considers the GED tests individually or the average score, there is no obvious cutoff point. In fact, there are a number of students with standard scores less than 45 who have completed university courses successfully, particularly if their mother tongue is not English, as is indicated indirectly by the ten students who failed English Expression but remained in the English Composition course at least three months. A significant trend in the data is that more and more students with low average standard scores are successful in succeeding years. This is partly a function of the introduction of remedial English in 1977 as a separate course and to the increasing help provided in the English 111-115 Composition courses since 1974. More recently a Study Skills course, and an English-as-a-Second Language course for non-native speakers have been introduced. It is expected, then, that data for 1978 and 1979 may show further increases in the success rate for low scoring students. Another minor factor that may have contributed to the trend was a decrease in the proportion of eight-month courses and an increase in the proportion of four-month courses. Since 1974, English and History courses have been conducted in four-month terms but some of the other subjects in 1974, 1975, and 1976 had eightmonth sessions.

Tables 3 and 4 represent only two of some 25 tables constructed to analyze the relationship between GED test scores and first-year university grades in English 111-115 (Composition), and English 121-122 (Literature), History 230, 240, or 242, Psychology 100, Sociology 100, and other introductory courses such as Philosophy, Anthropology, Political Science, and Geography. They show that there is considerable variability in grades obtained by students at all GED score levels but there is a slight trend to higher grades being associated with higher GED scores. There is a marked trend for failure rates to increase with lower GED test scores. The percentage of failures reaches 50 per cent for those with standard scores below 48.4 but it should be noted that the overall failure rate for first year courses is only about 25 per cent and such failure rates are similar to those of many first year courses on campus, and less than for some such as English composition. Moreover, several informal studies indicate that the grading standards for prisoner students is at least as conservative as for campus students.

The data in Table 3 and 4, and 23 similar tables is summarized in Table 5. This was done to determine if a cutoff point could be selected for the program that would really differentiate between successful and unsuccessful students. In Table 5, if one looks only at the failure rates for groups of more than ten, it is generally higher for standard scores of 48.5 to 53.4 than it is for standard scores of 53.5 to 58.4 . However, sometimes the failure rate is no larger or only lightly so. 
Table 2 Distribution of Students Who Completed Three Months or More of Program

on Various GED Test Standard Scores by Year of Entry

\begin{tabular}{|c|c|c|c|c|c|c|c|c|c|c|c|c|c|c|c|c|c|c|c|c|c|c|c|c|c|c|c|c|c|}
\hline \multirow{2}{*}{$\begin{array}{l}\text { Standard } \\
\text { Score }\end{array}$} & \multicolumn{4}{|c|}{ 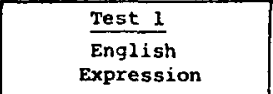 } & \multicolumn{5}{|c|}{$\begin{array}{l}\text { Test 2 } \\
\text { Social } \\
\text { Studies }\end{array}$} & \multicolumn{5}{|c|}{$\begin{array}{l}\frac{\text { Test } 3}{\text { Natural }} \\
\text { Science }\end{array}$} & \multicolumn{5}{|c|}{$\begin{array}{l}\text { Test } 4 \\
\text { Literary } \\
\text { Material }\end{array}$} & \multicolumn{5}{|c|}{ 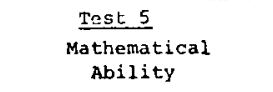 } & \multicolumn{5}{|c|}{$\begin{array}{c}\text { Average } \\
\text { Score }\end{array}$} \\
\hline & 14 & 75 & $\begin{array}{l}76 \quad 77 \\
\end{array}$ & $\begin{array}{c}\text { M11 } \\
\text { Years }\end{array}$ & 74 & 75 & 76 & 77 & $\begin{array}{c}\text { All } \\
\text { Years }\end{array}$ & 74 & 75 & 76 & 77 & $\begin{array}{c}\text { Al1 } \\
\text { Years }\end{array}$ & 74 & 75 & 76 & 77 & $\begin{array}{c}\text { Al1 } \\
\text { Years }\end{array}$ & 74 & 75 & 76 & 77 & $\begin{array}{c}\text { All } \\
\text { Years }\end{array}$ & 74 & 75 & 76 & 77 & $\begin{array}{c}\text { All } \\
\text { Years }\end{array}$ \\
\hline $75-$ Up & & & 1 & 1 & & & & & & & & & & & & & & 3 & 3 & & & & & & & & & & \\
\hline $70-74$ & & & & & & & & 3 & 3 & 1 & 1 & & 1 & 3 & 2 & & 1 & 2 & 5 & 1 & & & 1 & 2 & & & & 1 & 1 \\
\hline $65-69$ & & & 1 & 1 & 1 & 1 & 8 & 5 & 15 & 2 & 1 & & 3 & 6 & 5 & 1 & 3 & 2 & 11 & & 1 & 5 & 1 & 7 & 1 & 1 & 2 & 3 & 7 \\
\hline 63 & 1 & & 11 & 3 & & & & 4 & 4 & 1 & & & & 1 & 1 & & 1 & & 2 & 2 & & 1 & 1 & 3 & & & & & \\
\hline 62 & & 2 & & 2 & 1 & 2 & 1 & 1 & 5 & & 1 & & 3 & 4 & & 1 & 2 & 1 & 4 & 1 & & & 1 & 2 & 1 & & 2 & & 3 \\
\hline 61 & & & 1 & 1 & 3 & & & & 3 & & & 2 & 2 & 4 & 1 & & 2 & 2 & 5 & & & & 1 & 1 & & & & 1 & 1 \\
\hline 60 & 1 & 1 & 2 & 4 & & & 1 & 2 & 3 & 2 & & 7 & 4 & 13 & 2 & 2 & 2 & 1 & 7 & & & & & & 3 & & 2 & 3 & 8 \\
\hline 59 & & & 11 & 2 & & & 4 & & 4 & 3 & 2 & 4 & 6 & 15 & & & 1 & 1 & 2 & 2 & & & 4 & 6 & 1 & 1 & 3 & & 5 \\
\hline 58 & & & & & & & 1 & 2 & 3 & 1 & 1 & 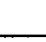 & 4 & 6 & & 1 & & & 1 & 2 & & 2 & 1 & 5 & & & 1 & 2 & 3 \\
\hline 57 & & 1 & & 1 & 3 & 1 & & 2 & 6 & 1 & 1 & 1 & 1 & 4 & 1 & & 2 & 4 & 7 & & & 3 & & 3 & 1 & & 2 & 3 & 6 \\
\hline 56 & 2 & & 11 & 4 & 2 & 2 & 1 & 3 & $B$ & & & & & & 1 & & 3 & 2 & 6 & & 2 & & 1 & 3 & 1 & 2 & & 4 & 7 \\
\hline 55 & & & 3 & 3 & & & 1 & 1 & 2 & 1 & & 2 & 3 & 6 & & & & & & 2 & 1 & 2 & 2 & 7 & 3 & 2 & 3 & 3 & 11 \\
\hline 54 & & 1 & 2 & 3 & 1 & 2 & 3 & 1 & 7 & 2 & 2 & & 2 & 6 & & 1 & 1 & 4 & 6 & 1 & 1 & & 6 & 8 & 1 & 1 & 2 & 3 & 7 \\
\hline 53 & & & $\begin{array}{ll}3 & 3 \\
\end{array}$ & 6 & 1 & 1 & & 3 & 5 & 1 & 1 & 1 & & 3 & & 1 & 2 & 2 & 5 & 1 & 1 & 2 & 3 & 7 & & & 1 & 1 & 2 \\
\hline 52 & 3 & & 14 & 8 & & 1 & 1 & 1 & 3 & & 2 & 1 & & 3 & 2 & & 1 & 2 & 5 & 1 & 1 & 1 & 1 & 4 & 1 & & 1 & 1 & 3 \\
\hline 51 & 1 & 1 & 13 & 6 & & & & 2 & 2 & & & 1 & 2 & 3 & & & & 1 & 1 & & 3 & 3 & 4 & 10 & & 2 & 1 & 1 & 4 \\
\hline 50 & 5 & 2 & 11 & 9 & 1 & 1 & & & 2 & & & 1 & 2 & 3 & & 2 & 1 & 4 & 7 & 2 & & 1 & 2 & 5 & & 2 & 1 & 5 & 8 \\
\hline 49 & 2 & 1 & $\begin{array}{ll}4 & 3 \\
\end{array}$ & 10 & & 1 & & & 1 & & & & 1 & 1 & & 1 & 1 & 1 & 3 & & & & 2 & 2 & 1 & & 1 & & 2 \\
\hline 48 & & & $\begin{array}{ll}1 & 2 \\
\end{array}$ & 3 & & & 1 & 1 & 2 & & & & 2. & 2 & & 1 & & & 1 & & 2 & 2 & 1 & 5 & & 2 & & 3. & 5 \\
\hline 47 & & 1 & 2 & 3 & & 1 & & 1 & 2 & & 1 & & & 1 & & 1 & & 1 & 2 & & 1 & & & 1 & & & & 1 & 1 \\
\hline 46 & & 1 & 24 & 7 & & 1 & & 2 & 3 & & & 1 & & 1 & & 1 & & 1 & 2 & & 1 & 1 & & 2 & & & 1 & 1 & 2 \\
\hline 45 & & & 2 & 2 & & & & 1 & 1 & & & & 1 & 1 & & & 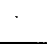 & 2 & 2 & & & 1 & 4 & 5 & & & 1 & 1 & 2 \\
\hline$\frac{44-\text { Dow }}{\text { Total }}$ & 15 & $\frac{3}{14}$ & $\begin{array}{rr}1 & 6 \\
28 & 38\end{array}$ & \begin{tabular}{l|}
10 \\
91
\end{tabular} & $\frac{1}{15}$ & 14 & $\frac{2}{24}$ & $\begin{array}{r}3 \\
38\end{array}$ & $\frac{6}{21}$ & 15 & $\frac{1}{11}$ & $\frac{1}{24}$ & 3 & $\frac{3}{91}$ & 15 & $\frac{2}{14}$ & $\frac{1}{24}$ & $\begin{array}{r}2 \\
38\end{array}$ & $\frac{1}{91}$ & & 14 & 24 & \begin{tabular}{r|}
2 \\
38
\end{tabular} & $\frac{2}{91}$ & & $\frac{1}{16}$ & 39 & $\frac{1}{38}$ & $\frac{2}{91}$ \\
\hline
\end{tabular}


Table 3 Distribution of Grades for Psychology 100 Grouped by GED English Expression Standard Scores

\begin{tabular}{|c|c|c|c|c|c|c|c|c|c|c|c|c|c|}
\hline \multirow{3}{*}{$\begin{array}{c}\text { English } \\
\text { Expression } \\
\text { Standard } \\
\text { Score }\end{array}$} & \multicolumn{10}{|c|}{ Psychology 100 Grades } & \multirow{3}{*}{$\mathrm{N}$} & \multirow{2}{*}{\multicolumn{2}{|c|}{$\%$}} \\
\hline & $\mathbf{F}$ & $\mathrm{D}$ & $\mathrm{c}$ & $\mathrm{C}+$ & B- & B & $\mathrm{B}+$ & A- & A & A+ & & & \\
\hline & 0 & 1 & 2 & 3 & 4 & 5 & 6 & 7 & 8 & 9 & & $\mathbf{F}$ & $F+D$ \\
\hline $63.5+u p$ & & & 1 & 1 & & & 1 & & & & 3 & 0 & 0 \\
\hline $58.5-63.4$ & & & 1 & & & 1 & & 1 & 1 & 1 & 5 & 0 & 0 \\
\hline $53.5-58.4$ & 1 & & 1 & 2 & & 2 & & & & & 5 & 17 & 17 \\
\hline $48.5-53.4$ & 5 & 1 & 3 & 3 & 2 & 1 & 1 & & 2 & & 18 & 28 & 33 \\
\hline up to 48.4 & 7 & 1 & 1 & 2 & 0 & 1 & 1 & 1 & & & 14 & 50 & 57 \\
\hline All groups & 13 & 2 & 7 & 8 & 2 & 5 & 3 & 2 & 3 & 1 & 46 & 28 & 33 \\
\hline
\end{tabular}

Table 4 Distribution of Grades for Lower Level History Courses Grouped by GED Social Studies Standard Scores

\begin{tabular}{|c|c|c|c|c|c|c|c|c|c|c|c|c|c|}
\hline \multirow{3}{*}{$\begin{array}{c}\text { Social } \\
\text { Studies } \\
\text { Standard } \\
\text { Score }\end{array}$} & \multicolumn{10}{|c|}{ History Grades } & \multirow{3}{*}{$\mathrm{N}$} & \multirow{2}{*}{\multicolumn{2}{|c|}{$\%$}} \\
\hline & $F$ & $\mathrm{D}$ & $\mathrm{C}$ & $\mathrm{Ct}$ & $B-$ & B & $B+$ & A- & $\mathrm{A}$ & At & & & \\
\hline & 0 & 1 & 2 & 3 & 4 & 5 & 6 & 7 & 8 & 9 & & F & $F+D$ \\
\hline $63+u p$ & 2 & 0 & 3 & 1 & 3 & 3 & 1 & 1 & & & 14 & 14 & 14 \\
\hline $58.5-63.4$ & $I$ & 1 & 4 & 0 & 1 & 3 & & & & & 10 & 10 & 20 \\
\hline $53.5-58.4$ & 3 & 2 & 2 & 0 & 0 & 3 & 0 & 1 & & & 11 & 27 & 45 \\
\hline $48.5-53.4$ & 3 & 0 & 1 & 1 & 0 & 1 & & & & & 6 & 50 & 50 \\
\hline up to 48.4 & 2 & 0 & 1 & 0 & 0 & 0 & 1 & & & & 4 & 50 & so \\
\hline All groups & 11 & 3 & 11 & 2 & 4 & 10 & 2 & 2 & & & 45 & 24 & 31 \\
\hline
\end{tabular}

\section{Conclusions}

With failure rates of only one in four for prisoner students with average standard scores of 53.5 to 58.4 there appears to be no reason for the University of Victoria requiring 58.5 on campus, as these failure rates are not too different from those frommany campus courses. Moreover, with decreased enrolments and many smaller classes on campus, there is currently a valid reason for having a completely open admission policy particularly when a student only wishes to take one or two courses and when it is noted that interest and motivation are likely to be high with mature students. To what extent these conclusions apply to other institutions will depend on similarity of standards, that is on the success ratio or pass/fail rate and on the selection ratio, the relative standard for entry to a program. When extra assistance in English composition and study skills is made available especially on a one to one basis as in the program described here, the failure rate for lower scoring GED students can undoubtedly be reduced. 
Table 5 Failure Rates in Per Cent for Various Subjects by Selected Standard Score Ranges on GED Tests

\begin{tabular}{|c|c|c|c|c|c|c|c|}
\hline \multirow{2}{*}{ Test } & \multirow{2}{*}{$\begin{array}{c}\text { Standard } \\
\text { Score }\end{array}$} & \multicolumn{6}{|c|}{ Subject } \\
\hline & & Composition & Literature & History & Psychology & Sociology & Others \\
\hline \multirow{2}{*}{ Average } & $53.5-58.4$ & 28 & $44^{*}$ & 23 & 23 & 0 & 18 \\
\hline & $48.5-53.4$ & 47 & $25 * *$ & $75 *$ & $43^{*}$ & $67^{\star}$ & $50^{*}$ \\
\hline English & $53.5-58.4$ & 20 & $0 * *$ & $14^{\star}$ & $17 *$ & $100 * *$ & $50^{*}$ \\
\hline Expression & $48.5-53.4$ & 26 & 25 & 24 & 28 & 15 & 24 \\
\hline Social & $53.5-58.4$ & 23 & $37 *$ & 27 & 23 & $25 * \star$ & 14 \\
\hline Studies & $48.5-53.4$ & 42 & $33^{\star *}$ & $50 *$ & $43^{\star}$ & $0 * *$ & $25 * *$ \\
\hline Natural & $53.5-58.4$ & 45 & $17 *$ & $40 *$ & $11 *$ & $17^{\star}$ & 36 \\
\hline Science & $48.5-53.4$ & 45 & $67 * *$ & $60 \star \star$ & $100 * *$ & $100 * *$ & $25^{\star *}$ \\
\hline Literary & $53.5-58.4$ & 29 & $50^{\star \star}$ & $40 *$ & 36 & $17 *$ & $25^{*}$ \\
\hline Material & $48.5-53.4$ & 47 & $17 *$ & $43^{*}$ & $43^{*}$ & $33 * *$ & $44^{\star}$ \\
\hline Math & $53.5-58.4$ & 23 & $33 *$ & 17 & 20 & $29 *$ & 21 \\
\hline Ability & $48.5-53.4$ & 32 & $50 * *$ & $13^{*}$ & 20 & $0^{*}$ & 31 \\
\hline $\mathrm{N}$ & & 76 & 23 & 45 & 46 & 25 & 49 \\
\hline
\end{tabular}

* - 10 cases or less

** -5 cases or less

Studies within institutions of higher learning using the GED or other selection instruments and conducted in a manner similar to the study reported here, that is with relatively open admission, could provide data for determining if cut-off points are useful, or whether there should be open admission. Moreover, if data are collected over a number of years as in this study, it is possible to determine if there are any trends and whether they can be related to the introduction of special measures. Such trend studies can have important implications for both programs and policies. Recently, for example, an English-as-a-Second Language course has been introduced in the prison program. It will be interesting to determine if the students who go through this course fare any better with university courses than similar students in the past who only received extra assistance in English composition.

Correlations and predictive validity coefficients provide little information. It is most important to study success ratios and selection ratios and trends over time. Information to conduct such studies can be collected routinely with little additional time and effort than is made now for the collection and compilation of student statistics for annual reports.

\section{REFERENCES}

Beusse, William W, Prediction of Participation and Achievement in the United States Armed Forces Institute (U.S.A.F.I.) General Educational Development (GED) Program, Springfield, Virginia: National Technical Information Service, $19 \mathrm{p}$, October 72.

Mehrens, W.A., and I.J. Lehmann, Measurement and Evaluation in Education and Psychology, (2nd ed.). New York: Holt, Rinehart \& Winston, 1978.

Sharon, Amiel, "Predicting the College Success of Non High School Graduates with the Tests of General Educational Development", Educational and Psychological Measurement, Vol. 32, 1055-1059, 1972. 